\title{
Association of obstructive sleep apnea with homocystein, nitric oxide and total antioxidant capacity levels in patients with or without coronary artery disease
}

Ebru ORTAÇ ERSOY
Hikmet FIRAT $^{2}$
Sevgi AKAYDIN $^{3}$
Yeşim ÖZKAN $^{4}$
Mine DURUSU $^{5}$
Gülbahar DARILMAZ YÜCE $^{6}$
Recai ERGÜN $^{6}$
Arzu TOPELi $^{1}$
Sadık ARDIÇ

${ }^{1}$ Department of Internal Medicine, Unit of Intensive Care, Faculty of Medicine, Hacettepe University, Ankara, Turkey

${ }^{1}$ Hacettepe Üniversitesi Tıp Fakültesi, iç Hastalıkları Anabilim Dalı, Yoğun Bakım Ünitesi, Ankara, Türkiye

${ }^{2}$ Laboratory of Sleep Disorders, Ankara Diskapi Yildirim Beyazit Teaching and Research Hospital, Ankara, Turkey

2 Ankara Dışkapı Yıldırım Beyazıt Eğitim ve Araştırma Hastanesi, Uyku Hastalıkları Laboratuvarı, Ankara, Türkiye

${ }^{3}$ Laboratory of Sleep Disorders, Faculty of Medicine, Gazi University, Ankara, Turkey

${ }^{3}$ Gazi Üniversitesi Tıp Fakültesi, Uyku Hastalıkları Laboratuvarı, Ankara, Türkiye

${ }^{4}$ Department of Biochemistry, Faculty of Medicine, Gazi University, Ankara, Turkey

${ }^{4}$ Gazi Üniversitesi Tıp Fakültesi, Biyokimya Anabilim Dalı, Ankara, Türkiye

${ }^{5}$ Department of Internal Medicine, Faculty of Medicine, Hacettepe University, Ankara, Turkey

${ }^{5}$ Hacettepe Üniversitesi Tıp Fakültesi, iç Hastalıkları Anabilim Dalı, Ankara, Türkiye

${ }^{6}$ Clinic of Chest Diseases, Ankara Diskapi Yildirim Beyazit Teaching and Research Hospital, Ankara, Turkey

${ }^{6}$ Ankara Dışkapı Yıldırım Beyazıt Eğitim ve Araştırma Hastanesi, Göğüs Hastalıkları Kliniği, Ankara, Türkiye

${ }^{7}$ Department of Chest Diseases, Ankara Diskapi Yildirim Beyazit Training and Research Hospital, Ankara, Turkey

7 Ankara Dışkapı Yıldırım Beyazıt Eğitim ve Araştırma Hastanesi, Göğüs Hastalıkları Bölümü, Ankara, Türkiye

\section{SUMMARY}

Association of obstructive sleep apnea with homocystein, nitric oxide and total antioxidant capacity levels in patients with or without coronary artery disease

Introduction: Obstructive sleep apnea (OSA) is associated with cardiovascular morbidity and mortality. Deficiency of nitric oxide

\section{Yazışma Adresi (Address for Correspondence)}

Dr. Ebru ORTAÇ ERSOY

Hacettepe Üniversitesi Tıp Fakültesi, İç Hastalıkları Anabilim Dalı, Yoğun Bakım Ünitesi, ANKKARA - TURKEY

e-mail: ebru.ortac@hacettepe.edu.tr 
(NO) and plasma levels of homocystein have been implicated in the pathogenesis of cardiovascular disease. OSA results in oxygen desaturation and arousal from sleep. Free oxygen radicals can be produced by hypoxia-reoxygenation. To test for the hypothesis that OSA is associated with cardiovascular morbidity, we investigated levels of homocystein, NO and total antioxidant capacity in OSA patients with and without coronary artery disease (CAD) in comparison with normal subjects and patients with CAD without OSA.

Materials and Methods: Polysomnography was performed in 27 patients who had a myocardial infarction and in 25 patients without evidence of CAD. Patients were grouped according their polysomnography results as OSA with CAD (group 1), OSA without CAD (group 2), CAD (group 3), and normal (group 4). Levels of homocystein, NO and total antioxidant capacity were determined after an overnight fasting. Data were analysed with parametric and non parametric statistical tests.

Results: According to apnea-hypopnea index (AHI) 44.4\% of CAD patients were OSA. After polysomnographic evaluation, the patients were re-distributed as follows: OSA with CAD ( $n=12)$, OSA without CAD $(n=14), C A D(n=15)$, and normal ( $n=11)$. Homocystein levels were higher in 3 groups compared to controls. AHI, MDI and desaturation time was higher in three -vessel disease compared to one and two- vessel diseases $(p<0.05)$. NO levels were correlated with the period of oxygen desaturation ( $r:-0.45$, $p=0.031$ ). The antioxidant capacity did not differ between OSA and healthy groups.

Conclusion: $O S A$ is frequent in CAD. AHI, MDI and desaturation time are higher in patients with severe CAD. It is important to evaluate OSA patients for CAD.

Key words: Sleep apnea, homocystein, myocardial infarction, hypoxia

\section{ÖZET}

Koroner arter hastalığı olan ve olmayan hastalarda obstrüktif uyku apnesinin homosistein, nitrik oksit ve total antioksidan kapasite düzeyleri ile ilişkisi

Giriş: Obstrüktif uyku apnesi (OUA) kardiyovaskuler morbidite ve mortalite ile ilişkili bir durumdur. OUA'li hastalarda endotel bağımIı vazodilatasyonda azalma meydana gelmektedir. Nitrik oksit eksikliği ve plazma homosistein düzeylerinin kardiyovasküler hastalıkların patogenezinde rolleri mevcuttur. OUA'de meydana gelen oksijen desaturasyonu ve arousallar hipoksi-reoksijenasyon yaparak serbest oksijen radikallerinin oluşumuna neden olur. Çalışma; OUA’nın kardiyovasküler morbidite ile ilişkisini göstermek ve koroner arter hastalığı (KAH) olan ve olmayan hastalarda homosistein, nitrik oksit ve total antioksidan kapasite seviyelerini karşılaştırmak için planlandı.

Materyal ve Metod: Miyokard infarktüsü geçirmiş 27 hastaya ve KAH olmayan 25 kontrol grubuna polisomnografi uygulandı. Polisomnografi sonrası hastalar OUA + KAH (grup 1), OU (grup 2), KAH (grup 3), normal (grup 4) olarak dört gruba ayrıldı. Homosistein, nitric oksit ve total antioksidan kapasite düzeyleri ölçüldü. Sonuçlar parametric ve nonparametric istatistiksel yöntemler ile analiz edildi.

Bulgular: Apne hipopne indeksine (AHi) gore KAH olanların \% 44.4'ünde OUA izlendi. Polisomnografi sonuçlarına gore hastalar OUA + KAH (n=12), OUA ( $n=14), K A H(n=15)$, normal $(n=11)$ gruplara ayrıldı. Homosistein seviyeleri grup 3 'te yüksek bulundu. AHi, Ortalama desaturasyon indeksi (MDI) ve desaturasyon süresi 3 damar hastalı̆̆ olan hastalarda tek dammar ve iki dammar hastalığı olan hastalara gore yüksek izlendi ( $p<0.05)$ Nitrik oksit seviyeleri oksijen desaturasyon süresi ile korele bulundu ( $r$ : -0.45; $p=0.031$ ). Antioksidan kapasite düzeyleri gruplar arası farklıık göstermiyordu.

Sonuç: OUA, KAH olanlarda sıktır. AHI, MDI ve desaturasyon süresi ağır KAH olanlarda sıktır. OUA hastalarının KAH açısından değerlendirilmesi önemlidir.

Anahtar kelimeler: Uyku apnesi, homosistein, miyokard infarktüsü, hipoksi

\section{INTRODUCTION}

Obstructive sleep apnea (OSA) is a serious health problem which affects $2-4 \%$ of the population with high morbidity and mortality rate (1-3). OSA has been considered to be an important risk factor for cardiovascular morbidity in recent years. OSA is characterized with apnea or hypopnea episodes due to collapse of upper air way or lack of respiration (4). These episodes may be long and may cause severe arterial hypoxemia, hypercapnia, systemic hyper- or hypotension and alterations in heart rate. These altereations may lead to coronary atherosclerosis and execarbate myocardial ischemia in patients with coronary heart disease (5). Relationship between sleep apnea and systemic hypertension, pulmonary hypertension, ischemic heart disease and stroke have been reported (6). Although underlying mechanisms are not clear yet, these relationships might partly be explained by elevated sympathetic activity associated with hypoxia (7-9). There is evidence indicating that oxidative stress and endothelial dysfunction playing a central role in the pathogenesis of atherosclerosis and cardiovascular morbidity $(10,11)$. 
To test for the hypothesis that OSA is associated with cardiovascular morbidity; our aim was to determine relationship between OSA and homocysteine, nitric oxide (NO), and antioxidant capacity levels, as markers of endothelial dysfunction in patients with or without coronary artery disease (CAD).

\section{MATERIALS and METHODS}

This study was conducted in the Sleep Disorders Diagnosis and Treatment Center of Chest Medicine and Tuberculosis Clinic in a large training and research hospital. The protocol was approved by the local ethics committe and all participants signed informed consent before their enrollment.

\section{Patients}

Patients who were hospitalised because of acute myocardial infarction respectively for two months duration were screned for snoring and sleep disturbances with Epworth sleepiness scale. Totally 78 patients were hospitalised in this time period.

Of these 52 patients who were having complaint of snoring and treated in the coronary care unit because of acute myocardial infarction were conducted to study. All patients were diagnosed as having CAD with coronary angiography. All patients were male, younger than 70 years. There weren't use of alcohol or any sedative drugs before. All of these 52 patients were called for undergoing polysomnography, by phone 3-6 months after hospital discharge. Twenty nine of patients accepted to undergo one-night complete polysomnography. All patients had undergone echocardiography, all of their ejection fractions were greater than $40 \%$ and then one night polysomnography applied to this patients group. As a result, patients with CAD and whose sleep efficiency was higher than $60 \%$ were taken as "CAD" group ( $n=27)$. (At two of them sleep efficiency was lower than $60 \%$ ).

\section{Controls}

Controls selected from out patient clinic whom were disturbed from snoring. The controls with similar demographic features who referred to sleep clinic with common snoring compliant were detected. Without evidence of CAD (no history of CAD, normal ECG findings on application and having no symptoms of CAD) were taken as "control" group $(n=25)$. One-night complete polysomnography was also applied to the control group. All of their sleep efficiency was higher than $60 \%$. There weren't use of alcohol and any sedative drugs. There weren't any co morbidies like diabetes or hypertension.

\section{Polysomnography}

One-night complete polysomnography that includes 4-channel EEG (C3-A2, C4-A1, O1, A2, O2-A1) with Somnologica 3.2 program (16-channel Embla Flaga), EMG (Sub-mental and Tibialis EMG), ECG, oronasal airflow (by thermistor), respiratory thoracic movements, respiratory abdominal movements, snoring, body position and pulse oximetry was applied to all patients and controls.

Sleep efficiency (\% of sleep time), AHI, mean desaturation index (MDI) (mean desaturation number per hour), number of desaturation (number of desaturation throughout polysomnography), lowest oxygen saturation, mean oxygen saturation, oxygen desaturation time (time that passes while $\mathrm{SaO}_{2}<90 \%$ ) were recorded.

\section{Blood Sample Collection, Storage and Measurements for Homocysteine, NO and Total Anti-Oxidant Capacity}

Blood samples were collected in heparinated tubes for plasma and standard tubes for serum samples after 12 hours of fasting next day after polysomnography. Samples were centrifugated at $3000 \mathrm{rpm}$ for $15 \mathrm{~min}$ utes, were stored at $-70^{\circ} \mathrm{C}$ until evaluation.

\section{Homocysteine Measurement}

Total homocysteine levels were measured by the flourometric HPLC methods with some modification. Treatment of the plasma sample prior to application on the analytical column included reduction with trin-butilphosphine, protein precipitation with perchloric acid and derivatization with 7-fluorobenzo-2-oxa1,3-diazole-4-sulphonate. Fluorescence intensities were measured with excitation at $385 \mathrm{~nm}$ and emission at $515 \mathrm{~nm}$.

\section{Nitric Oxide (NO2 + NO3) Measurement}

Serum NO levels were measured as the sum of nitrate and nitrite levels. Serum samples were deproteinized with ethanol and were centrifuged at 5000 g. $100 \mu \mathrm{L}$ of the supernatant were loaded in the polystyrene microtiter plate, then $100 \mu \mathrm{L}$ saturated $\mathrm{VCl} 3$ solution in $1 \mathrm{M} \mathrm{HCl}$ was added to convert nitrate to nitrite. 
After the addition of $100 \mu \mathrm{L}$ Griess reagent, plates were incubated at $37^{\circ} \mathrm{C}$ for 45 minutes, and absorbance of the samples were measured by using a plate reader at $540 \mathrm{~nm}$.

\section{Total Antioxidant Capacity Measurement}

$5 \mu \mathrm{L}$ serum sample was added to $200 \mu \mathrm{L}$ reagent 1 (Fe +2 -o-dianisidine). After the first measurement at the $444 \mathrm{~nm}$ in Elisa Reader, $10 \mu \mathrm{L}$ R2 reactive $\left(\mathrm{H}_{2} \mathrm{O}_{2}\right)$ was added to the mixture and the last absorbance is taken when the reaction trace draws a plateau line (about 17 minutes after the mixing). The difference between the first absorbance and last one was calculated. The results were calculated as Trolox equivalent.

\section{Statistical Method}

SPSS 18.0 (Chicago Illinois) software was used for statistical analysis. T-test and Mann Whitney-U test were used when comparing two groups where appropriate. Kruskal Wallis test was used for comparing four groups. Mann Whitney- $U$ test with Bonferroni correction was used for evaluation of binary comparisons when significant differences were found between groups. Results are reported as mean \pm SD for continuous variable.

\section{RESULTS}

Twenty seven of 52 patients which were included in study had CAD. Apnea hypopnea index (AHI) was higher than 5 in $44.4 \%(n=12)$ of 27 patients. Mean $\mathrm{AHI}$ score of this group was found as $16.1 \pm 9.7$. Patients with CAD have been grouped as having onevessel, two- vessels or three- vessels coronary artery disease according to angiography reports. Most of the patients with CAD had one- or two-vessel disease, while those with OSA and CAD had two- or threevessel disease.

According to polysomnography results whole groups (patients and controls) were classified into four groups with regard to $\mathrm{AHI}(\mathrm{AHI}>5$ as $\mathrm{OSA} ; \mathrm{AHI}<5$ as normal): Group 1: Normal $(n=10)$; group 2: OSA $(n=15)$; group 3: CAD $(n=15)$; group 4: CAD with OSA $(n=12)$.

In patients with CAD with OSA, 2 patients had $\mathrm{AHI}$ higher than 20. There wasn't any difference between mean ages and body mass indexes (BMI) of groups. Epworth Scale was significantly higher in OSA group than the others (Table 1).

Polysomnographic findings of the patients are summarized in Table 2. There wasn't any difference between sleep stages of groups.

Mean desaturation index (MDI), number of desaturation, lowest oxygen saturation and mean oxygen saturation of groups were examined. Lowest mean oxygen saturation $(74.2 \pm 2.6)$ was obtained in OSA

Table 1. Age, BMI, AHI and coronary angiography results of groups

\begin{tabular}{|c|c|c|c|c|c|}
\hline & $\begin{array}{l}\text { Normal } \\
(n=10)\end{array}$ & $\begin{array}{c}\text { OSA } \\
(n=15)\end{array}$ & $\begin{array}{c}\text { CAD } \\
(n=15)\end{array}$ & $\begin{array}{c}\text { OSA + CAD } \\
(n=12)\end{array}$ & p \\
\hline Age & $48.8 \pm 6.6$ & $53.7 \pm 8.1$ & $53.2 \pm 7.2$ & $54.7 \pm 6.9$ & 0.09 \\
\hline BMI & $26.2 \pm 1.6$ & $27.5 \pm 3.2$ & $25.7 \pm 3.6$ & $28 \pm 3.4$ & 0.07 \\
\hline $\mathrm{AHI}$ & $2.7 \pm 1.9$ & $41.6 \pm 27.4$ & $1.9 \pm 1.2$ & $16.2 \pm 9.7$ & 0.0 \\
\hline One vessel (n) & & & 7 & 2 & \\
\hline Two vessels (n) & & & 6 & 5 & \\
\hline Three vessels (n) & & & 2 & 5 & \\
\hline Epworth scale & $7.3 \pm 3.8$ & $10.2 \pm 5.5$ & $6.3 \pm 5.4$ & $5.0 \pm 3.1$ & 0.03 \\
\hline
\end{tabular}

\section{Table 2. Distribution of sleep stages in patients with or without OSA}

\begin{tabular}{|lcccc|}
\hline OSA & Stage 0 & Stage 1 & Stage 2 & Stage 3 \\
\hline No $(\mathrm{n}=25)$ & $14.2 \pm 12.3$ & $4.7 \pm 3.2$ & $44.9 \pm 12.4$ & $24.4 \pm 7.3$ \\
Yes $(\mathrm{n}=27)$ & $12.2 \pm 7.4$ & $5.9 \pm 6.5$ & $45.7 \pm 11.5$ & $20.3 \pm 11.7$ \\
$\mathrm{p}$ & 0.65 & 0.88 & 0.84 & 0.15 \\
\hline OSA: Obstructive sleep apnea, $\mathrm{p}<0.05=$ Significant. & & & \\
\hline
\end{tabular}


group (Group 2). Number of desaturation and MDI were higher in OSA group (Group 2) (Table 3).

There was no statistically significant difference between groups with regard to $\mathrm{NO}$ and total antioxidant capacity (Table 3). However, there was statistically significant difference in homocysteine values between healthy controls (Group 1) and the other groups (Group 2, 3, 4) $(p<0.05)$. Average of homocysteine levels in normal group was lower than all groups. Highest values for homocysteine were observed in group 4 (CAD with OSA).

There was no correlation between homocysteine levels and oxygen desaturation time (time that passes while $\left.\mathrm{SaO}_{2}<90 \%\right)$ and mean apnea time $(r=0.165$, $p>0.05$ and $r=0.244, p>0.05)$. However, nitric oxide levels were significantly correlated with oxygen desaturation time $(r=-0.45, p<0.05)$.

In patients with CAD, desaturation time was significantly longer and $\mathrm{AHI}, \mathrm{MDI}$ were higher in patients with three-vessel disease from patients with one and two -vessel disease (Table 4).

\section{DISCUSSION}

In this study we firstly demonstrated that OSA was frequent in CAD patients. $\mathrm{AHI}, \mathrm{MDI}$ and desaturation time were higher in patients with three -vessel disease, indicating level and duration of hypoxia might be related with severity of CAD.

Secondly homocystein levels were higher in patients with OSA only, CAD only and OSA with CAD (group $2,3,4)$ and $\mathrm{NO}$ levels were inversely correlated with length of desaturation time, suggesting that hypoxia seen in OSA might be the cause of hemodynamic instability in OSA and atherogenesis though decreased synthesis of NO. Finally antioxidant capacity levels were not different between groups.

The increased association with vascular morbidity including myocardial infarction is a major concern in OSA. Patients with OSA demonstrate both acute and chronic hemodynamic changes attributable to the sleep-disordered breathing (12-14). Sympathetic hyperactivity is an important factor in the development of OSA and cardiovascular disease. Lanfranchi

Table 3. Number of desaturation, MDI, lowest oxygen saturation and mean oxygen saturation, homocysteine, nitric oxide and total anti-oxidant capacity of all groups

\begin{tabular}{|lccccc} 
& $\begin{array}{c}\text { Normal } \\
(\mathbf{n = 1 0})\end{array}$ & $\begin{array}{c}\text { OSA } \\
(\mathbf{n = 1 5})\end{array}$ & $\begin{array}{c}\text { CAD } \\
(\mathbf{n = 1 5})\end{array}$ & $\begin{array}{c}\text { CAD + OSA } \\
(\mathbf{n = 1 2})\end{array}$ & $\mathbf{p}$ \\
\hline Desaturation time (minute) & $20.9 \pm 51.3$ & $131.4 \pm 117.4$ & $10.8 \pm 33.3$ & $12.3 \pm 9.7$ & 0 \\
Desaturation number & $29.45 \pm 5.16$ & $115.00 \pm 18.29$ & $26.33 \pm 7.57$ & $97.00 \pm 18.70$ & 0 \\
AHI & $2.7 \pm 1.9$ & $41.6 \pm 27.4$ & $1.9 \pm 1.2$ & $16.2 \pm 9.7$ & 0 \\
MDI & $4.8 \pm 0.7$ & $17.8 \pm 2.4$ & $4.2 \pm 1.2$ & $14.5 \pm 2.7$ & 0 \\
Lowest oxygen saturation (\%) & $84.8 \pm 1.0$ & $74.2 \pm 2.6$ & $83.2 \pm 1.4$ & $83.3 \pm 0.7$ & 0 \\
Mean oxygen saturation $(\%)$ & $93.3 \pm 0.5$ & $89.4 \pm 4.3$ & $93.4 \pm 0.4$ & $93.0 \pm 0.3$ & 0.04 \\
$\begin{array}{l}\text { Nitric oxide }(\mu \mathrm{mol} / \mathrm{L}) \\
\text { (mean } \pm \text { SD) }\end{array}$ & $73.8 \pm 17.8$ & $66.7 \pm 20.3$ & $77.6 \pm 16.6$ & $83.7 \pm 26.9$ & 0.89 \\
$\begin{array}{l}\text { Homocystein }(\mu \mathrm{mol} / \mathrm{L}) \\
\text { (mean } \pm \text { SD) }\end{array}$ & $12.3 \pm 2.5$ & $14.3 \pm 2.7$ & $16.4 \pm 6.8$ & $16.9 \pm 4.6$ & 0.04 \\
$\begin{array}{l}\text { Total antioxidant capacity }(\mu \mathrm{mol} / \mathrm{L}) \\
\text { (mean } \pm \text { SD) }\end{array}$ & $2.1 \pm 0.3$ & $2.2 \pm 0.4$ & $2.2 \pm 0.2$ & $2.2 \pm 0.3$ & 0.38 \\
\hline
\end{tabular}

OSA: Obstructive sleep apnea, CAD: Coronary artery disease, AHI: Apnea hypopnea index, MDI: Mean desaturation index, $\mathrm{p}<0.05=$ Significant.

Table 4. MDI, AHI and desaturation time of CAD patients

\begin{tabular}{|lcccc|} 
& $\begin{array}{c}\text { One Vessel } \\
\mathbf{n = 9}\end{array}$ & $\begin{array}{c}\text { Two Vessels } \\
\mathbf{n = 1 1}\end{array}$ & $\begin{array}{c}\text { Three Vessels } \\
\mathbf{n = 7}\end{array}$ & $\mathbf{p}$ \\
\hline $\mathrm{MDI}$ & $4.5 \pm 5.1$ & $11.1 \pm 5.7$ & $12.7 \pm 7.5$ & 0.038 \\
$\mathrm{AHI}$ & $3.3 \pm 3.8$ & $9.8 \pm 13$ & $12.2 \pm 6.4$ & 0.035 \\
Desaturation time (min) & $3.2 \pm 2.8$ & $3.1 \pm 3.1$ & $35.2 \pm 44.4$ & 0.001 \\
\hline MDI: Mean desaturation index, AHI: Apnea hypopnea index, CAD: Coronary artery disease, $\mathrm{p}<0.05=$ Significant. \\
\hline
\end{tabular}


et al. suggested that sleep fragmentation caused by OSA leads to hemodynamic changes and sympathetic hyperactivity (15). Sympathetic activity increases thrombotic events by causing platelet activation and hypertension. This also plays important role in pathogenesis of atherogenesis $(16,17)$. Repetitive hypoxemia increases myocardial ischemia and severity of disease in patients with cardiovascular disease (1821). Therefore, patients with cardiovascular disease should be assessed for respiratory disorders during sleep. In our study, $44.4 \%$ of male patients who had a myocardial infarction had AHI higher than 5. This result once again demonstrated the importance of questioning patients with CAD for OSA.

Hung et al. assessed patients with OSA and myocardial infarction and reported a mean oxygen saturation of $86.1 \%$ (22). In paralel to this finding, we also showed a mean value of lowest $\mathrm{SaO}_{2}$ of $83.2 \pm 1.4 \%$ in patients with CAD and $83.3 \pm 0.7 \%$ in patients with CAD with OSA. In our study $\mathrm{MDI}, \mathrm{AHI}$ and desaturation time $\left(\mathrm{SaO}_{2}<90 \%\right)$ have been found to be significantly higher in patients with severe coronary atherosclerosis (three-vessel disease). Myocardial infarction might have been triggered by hypoxia that occurred as a result of long apnea period. Hayashi et al. also found a positive correlation between hypoxia (MDI) and severity of atherosclerosis (17).

Hyperhomocysteinemia has been mentioned as a risk factor for peripheral vascular diseases, CAD and cerebrovascular diseases in many studies (23-25). A meta-analysis by Baushey et al. demonstrated that a $5 \mu \mathrm{mol} / \mathrm{mL}$ elevation in homocystein level increases the cardiovascular risk $60 \%$ in men and $80 \%$ in women (24). Moreover, Lavia et al. demonstrated patients with OSA showed that homocysteine levels were significantly higher in OSA with CAD patients than patients who had only OSA or had only CAD. This suggests that OSA with CAD might have additive effect in causing oxidative stress. But in another study there were not any increase in homocystein levels in patients with OSA $(26,27)$. In our study, homocysteine levels were higher in patients with OSA, CAD and OSA with CAD than healthy controls.

Endothelial cells detoxify homocysteine by increasing nitric oxide $(\mathrm{NO})$ release. However, high homocysteine levels reduce NO production by impairing endothelium function and induce atherosclerosis
(28). Homocysteine attenuates the anti-thrombotic effect of endothelium and inactivates $\mathrm{NO}$ via oxygen radicals (29). Studies have suggested that impaired endothelium dependent vasodilatation occurs as a result of decreased NO in OSA (16,30-33). In our study, NO levels were lower and homocystein levels were higher in OSA group $(66.7 \pm 20.3 ; 14.3 \pm 2.7$ respectively) when compared to the healthy control group $(73.8 \pm 17.8 ; 12.3 \pm 2.5$ respectively), however the difference did not reach statistical significance probably due to the small number of the enrolled patients. This could be due to interaction between homocysteine and nitric oxide.

We found a negative correlation between NO levels and long desaturation time, which might be due to the hemodynamic changes associated with apnea and intermittent nocturnal oxygen desaturation. $\mathrm{NO}$ might play a role in the pathogenesis of hemodynamic changes and atherosclerosis seen in OSA. Moreover, this might be reversible by use of continuous positive airway pressure (CPAP) treatment $(32,33)$.

Measurement of total anti-oxidant capacity didn't reveal significant results because it might be affected from other factors.

Total anti-oxidant capacity can decrease with usage in non enzymatic anti-oxidant system in conditions that increase oxidative stress such as hypoxia/reoxygenation. In our study, we evaluated the difference between groups by measuring non enzymatic anti-oxidant capacity; however, we found no significant difference. Christou et al. demonstrated a reduction in anti-oxidant capacity levels in patients with severe OSA, but also could not find any difference between patients with OSA and control group in their study (34).

There are some limitations of our study; firstly small number of enrolled patients might affect the results and decrease the statistical power. Secondly, selection of patients from snoring patients may affect OSA frequency. We should screen all patients. Thirdly, we didn't check the nutritions and new medication of patients after hospital discharge, which could effect the NO and total anti-oxidant capacity levels. And finally in control group CAD was excluded with only ECG findings. We should apply stress test. However, it might be speculated that intermittent nocturnal oxygen desaturation and/or apnea can cause CAD. 
In conclusion, CAD patients should be evaluated for presence of OSA and treating patients with OSA might decrease cardiovascular mortality and morbidity.

\section{CONFLICT of INTEREST}

None declared.

\section{REFERENCES}

1. Young T, Peppard EP, Gottieb DJ. Epidemiology of obstructive sleep apnea. A population health perpective. Am J Respir Crit Care Med 2002;165:1217-39.

2. Stradling JR. Obstructive sleep apnea. Definitions, epidemiyoloji and natural history. Thorax 1995;50:683-9.

3. He J, Kryger MH, Zorick FJ, Conway W, Roth T. Mortality and apnea index in obstructive sleep apnea: experience in 385 male patients Chest 1988;94:9-14.

4. The Report of American Academy of Sleep Medicine Sleeprelated breathing disorders in adults: recommandations for syndrome definition and measurement technigues in clinical research. Sleep 1999;22(5):326-31.

5. Stoohs R, Guilleminault C. Cardiovascular changes associated with obstructive sleep apnea syndrome. I Appl Physiol 1992; 72(2):583-9.

6. Parish JM, Somers VK. Obstructive sleep apnea and cardiovascular disease. Mayo Clin Proc 2004;79(8):1036-46.

7. Somers VK, Dyken ME, Mark AL, Abboud FM. Sympatetic nerve activity during sleep in normal subjects. N Engl I Med 1993;328:303-7.

8. Ringler J, Basner RC, Shannon R, Schwartzstein R, Manning $H$, Weinberger $S E$, et al. Hypoxemia alone does not explain blood pressure elevations after obstructive apneas. I Appl Physiol 1990;69:2143-8.

9. Somers VK, Mark AL, Zavala DC, Abboud FM. Contrasting effects of hypoxia and hypercapnia on ventilation and sympatetic activity in humans. I Appl Physiol 1989;67:2101-6.

10. Graham IM, Daly LE, Refsum HM, Robinson K, Brattström $L E$, Ueland PM, et al. Plasma homocysteine as a risk factor for vascular disease. The European concerted action project. JAMA 1997;277:1775-81.

11. Lavie L. Obstructive sleep apnea syndrome- an oxidative stress disorder. Sleep Med Rev 2003;7:35-51.

12. Hedner JA, Wilcox I, Sullivan CE. Speculations on the interaction between vascular disease and obstructive sleep apnea. In: Sullivan CE (ed). Sleep and Breathing. $2^{\text {nd }}$ ed. Philadelphia: Saunders; 1994.

13. Parish JM, Shepard JW. Cardiovascular effects of sleep disorders. Chest 1990;97:1220-6.

14. Weiss IW, Remsburg S, Garpestad E, Ringler J, Sparrow D, Parker JA. Hemodynamic consequences of obstructive sleep apnea. Sleep 1996;19(5):388-97.
15. Lanfranchi PA, Braghiroli A, Bosimini E, Mazzuero G, Colombo R, Donner F, et al. Prognostic value of nocturnal Cheyne-Stokes respiration in chronic heart failure. Circulation 1999;99:1435-40.

16. Schulz R, Mahmoudi S, Hattar K, Sibelius U, Olschewski $H$, Mayer $K$, et al. Enhanced release of superoxide from polymorphonuclear neutrophils in obstructive sleep apnea. Impact of continuous positive airway pressure therapy. Am J Respir Crit Care Med 2000;162:566-70.

17. Hayashi M, Fujimoto K, Urishibata K, Uchikawa S, Imamura $H$, Kubo K. Nocturnal oxygen desaturation correlates with severity of coronary atherosclerosis in coronary artery disease. Chest 2003;124:936-41.

18. Shah NA, Yaggi HK, Concato J, Mohsenin V. Obstructive sleep apnea as a risk factor for coronary events or cardiovascular death. Sleep Breath 2010;14(2):131-6.

19. Lee CH, Khoo SM, Tai BC, Chong EY, Lau C, Than Y, et al. Obstructive sleep apnea in patients admitted for acute myocardial infarction. Prevalence, predictors, and effect on microvascular perfusion. Chest 2009;135(6): 1488-95.

20. Gainer JL. Hypoxia and atherosclerozis: re-evaluation of an old hypothesis. Atherosclersis 1987;68:263-6.

21. Deanfield JE, Maseri A, Selwyn AP, Ribeiro P, Chierchia S, Krikler S. Myocardial ischemia during daily life in patients with stable angina: its relation to symptoms and heart rate changes. Lancet 1983;2:753-8.

22. Humg J, Whitford EG, Parsons RW, Hillman DR Association of sleep apnea with Myocardial infarction in men Lancet 1990;336:261-64 12.

23. Graham IM, Daly EL, Refsum HM, Robinson K, Brattström $L E$, Ueland PM, et al. Plasma homocysteine as a risk factor for vascular disease. The European concerted action project. JAMA 1997;277:1775-81.

24. Bousney CJ, Beresford SAA, Omenn GS, Motulsky AG. A qualitative assesment of plasma homocysteine as a risk factor for vascular disease: probabl benefits of increasing folic acid intakes. JAMA 1995;274:1049-57.

25. Nygard O, Nordrehurg JE, Refsum HE, Ueland PM, Farstad $M$, Vollset SE. Plasma homocysteine levels and mortality in patients with coronary artery disease. N Engl J Med 1997;337:230-6.

26. Lavie L, Perelman A, Lavie P. Plasma homocysteine levels in obstructive sleep apnea. Association with cardiovasculer morbidity. Chest 2001;120:900-8.

27. Svatikova A, Wolk R, Magera MJ, Shamsuzzaman AS, Phillips BG, Somers VK. Plasma homocystein in obstructive sleep apnea. Eur Heart J 2004;25,1325-9.

28. Schlaish MP, John S, Jacobi J, Lackner KJ, Schmieder RE. Mildly elevated homocystein concentrations impair endothelium dependent vasodilatation in hypercholesterolemic patients. Atherosclerosis 2000;153:383-9.

29. Faraci FM. Hyperhomocysteinemia. A million ways to lose control. Atheroscler Thromb Vasc Biol 2003;23:371-3. 
Association of obstructive sleep apnea with homocystein, nitric oxide and

total antioxidant capacity levels in patients with or without coronary artery disease

30. Kato M, Thompson R. Impairment of endothelium dependent vasodilatation of resistance vessels in patients with obstructive sleep apnea. Circulation 2000;109:2607-10.

31. Feng J, Zhang D, Chen B. Endothelial mechanisms of endothelial dysfunction in patients with obstructive sleep apnea. Sleep Breat 2012;16(2):283-94.

32. Ip MS, Lam B, Chan $L Y$, Zheng L, Tsang KW, Fung PC, et al. Circulating nitric oxide is supressed in obstructive sleep apne and reversed by nasal continious positive airway pressure. Am J Respir Crit Care Med 2000;162:2166-71.
33. Schulz R, Schmidt D, Blum A, Lopes-Ribeiro X, Lücke C, Mayer $K$, et al. Decreased plasma levels of nitric oxide derivatives in obstructive sleep apnoea: response to CPAP therapy. Thorax 2000;55:1046-51.

34. Christou K, Moulas AN, Pastaka C, Gourgoulianis KI. Antioxidant capacity in obstructive sleep apnea patients. Sleep medicine 2003;4:225-8. 